\title{
A Multidisciplinary Approach to Analyzing Questions of Justice Issues in Urban Greenspace
}

\author{
Adriana A. Zuniga-Teran ${ }^{1,2, *}$ and Andrea K. Gerlak ${ }^{1,3}$ \\ 1 Udall Center for Studies in Public Policy, University of Arizona, 803 E. 1st St, Tucson, AZ 85719, USA; \\ agerlak@email.arizona.edu \\ 2 School of Landscape Architecture and Planning, University of Arizona, 1040 N Olive Rd., Tucson, \\ AZ 85721, USA \\ 3 School of Geography and Development, University of Arizona, 1064 E Lowell St., Tucson, AZ 85719, USA \\ * Correspondence: aazuniga@email.arizona.edu
}

Received: 30 April 2019; Accepted: 24 May 2019; Published: 30 May 2019

check for updates

\begin{abstract}
Greenspace can alleviate many of the negative effects of urbanization and help enhance human well-being yet, in most cities in the world, greenspace is inequitably distributed. In western societies, wealthy white neighborhoods typically have more access to greenspace, constituting an environmental and social justice issue. Although scholars from multiple disciplines and academic domains study questions of justice in greenspace, the scholarship remains fragmented. The purpose of this qualitative review is to explore the diverse disciplinary approaches to justice in urban greenspace to identify patterns and trends in how justice is conceptualized and realized. We analyze a set of case studies across multiple disciplines using a sample of 21 peer-reviewed articles following the framework set out by Bulkeley and colleagues that conceptualizes justice according to recognition, distribution, procedures, rights, and responsibilities. Our results suggest that the various solutions proposed in the diverse streams of scholarship often call for solutions that transcend individual disciplinary boundaries. This finding supports the need for collaborative and cross-disciplinary work to effectively address injustice in urban greenspace. In an effort to integrate findings, we identify five main objectives that need to be addressed by scholars, built environment practitioners, and policymakers, which include: (1) appropriate funding mechanisms for long-term maintenance; (2) recognition of safety concerns; (3) connectivity of greenspace; (4) multifunctionality in greenspace design; and (5) community engagement.
\end{abstract}

Keywords: greenspace; environmental justice; urban resilience; green infrastructure; community engagement

\section{Introduction}

Greenspace, seen as parks, sport fields, golf courses, greenways, gardens, green infrastructure, urban forests, tree canopy cover, and vegetation can alleviate some of the negative effects of urbanization and enhance human wellbeing [1-5]. Greenspace also provides many ecosystem services that can help cities adapt to climate change and increase resilience (e.g., improved air quality, reduced flooding risk and heat island effect) [6,7] and provides habitat that supports biodiversity [8]. A decline of greenspace per capita in cities as a consequence of urbanization has reduced opportunities for greenspace [1,9]. Yet, even when greenspace is available, it is often not equally distributed within cities across the world. Wealthy white neighborhoods in western societies typically have more access to greenspace representing a social and environmental justice issue [4].

Environmental justice scholars have traditionally focused on environmental risks (e.g., proximity to landfills, emitters of toxic chemicals, polluted water bodies), however, access to environmental amenities, including access to greenspace in cities, is increasingly considered as an environmental 
justice issue $[4,10,11]$. Greenspace is not a well explored topic under the environmental justice literature, perhaps because it is not as compelling as other topics with negative connotations such as waste, air pollution, and climate change [12]. In addition, greenspace is challenging to study because it can serve multiple functions and have different meanings [12].

Greenspace justice has been studied by a diverse set of disciplinary sub-fields and theoretical approaches [13-15]. One of the most prominent disciplines studying justice issues around greenspace is public health around issues of urban health equity and opportunities for physical activity, improving cognitive abilities and mental health, and decreasing crime [14]. Political ecologists are also interested in these issues in an effort to distill the complex power relations that result in the social creation of unequal environments [16]. Similarly, urban foresters examine inequalities in the spatial distribution of trees in cities in terms of the provision of ecosystem services, recognizing the need for a cross-sectoral and interdisciplinary approach [17]. The implications of environmental justice in greenspace planning are studied by scholars interested in climate change adaptation and resilience, where vulnerable communities are disproportionately and negatively affected [18]. Landscape architects, who are responsible for translating policies and social needs into greenspace design, need integrated research that examines these environmental and social justice challenges [19]. Finally, researchers who study urban water security (e.g., stormwater management, water quality, aquifer recharge), recognize that greening initiatives are sometimes too narrowly oriented and that a broader focus is needed to combine green and grey infrastructure and address social equity and sustainability [20].

Although scholars from multiple disciplines and academic domains study environmental justice issues around greenspace in cities, the scholarship remains fragmented [21]. The few related reviews that exist are more narrowly focused on one aspect of greenspace; for example, on issues of food justice and urban agriculture and planning [22], the relationships between greenspace, gender, and health [13], and motivations for urban greening projects [23]. Other reviews are more broad, interdisciplinary approaches to environmental justice, but lack a particular focus on urban greenspace [15]. It remains uncertain how to address greenspace injustice issues on the ground and integrating different perspectives (e.g., recreation, stormwater management, conservation of biodiversity, landscape design), and how a variety of built environment professionals can address these issues in their own work.

To address this gap, the purpose of this study is to explore and integrate the trends and patterns in how environmental justice around greenspace in cities is conceptualized and realized in diverse streams of scholarship and translate these findings into lessons for practitioners. We conduct an integrative review across multiple disciplines using a sample of 21 peer-reviewed articles following the justice framework set out by Bulkeley et al. [24]. In the next section, we begin by engaging the theoretical background of environmental justice, including conceptual frameworks that have been developed in previous studies. Then, in section three, we describe our approach to this integrative review of greenspace justice literature according to disciplines that influence the built environment. In section four, we present our findings on recognition, distribution and procedures, and rights and responsibilities. In the final section, we present our conclusions and propose a conceptual framework for greenspace justice that translates our findings into lessons for scholars, built environment practitioners, and policymakers interested in addressing greenspace injustices.

\section{Theoretical Background}

In addition to a social movement, environmental justice has emerged as an academic domain that has been studied from multiple disciplines since the 1970s, including geography, public policy and administration, urban planning, sustainability, law, and political science $[15,25]$. Environmental justice is a broad concept that examines the power relations, social movements, and politics behind the unfair distribution of risks and resources [26]. It can be seen as an empowering and integrative framework for multiple social movements [25]. The U.S. Environmental Protection Agency (EPA) defines environmental justice as "the fair treatment and meaningful involvement of all people regardless of race, color, national origin, or income, with respect to the development, implementation, and enforcement of environmental 
laws, regulations, and policies" [27]. Related to justice are concepts of inequality, which highlight the uneven spatial distribution of environmentally related risks or resources across populations; and inequity, which considers the social unfairness of the spatial distribution of resources and risks [12,26].

Environmental justice emerged in the U.S. as a consequence of civil rights and anti-toxic movements, and now is being used not only in policy making and academic research, but also for political debate and environmental campaigning around the world and across all scales-from street level to global [12]. Street level local issues include unwanted land uses, access to greenspace, or poor transit while global issues refer to vulnerable countries that will suffer the impacts of climate change the most, and yet, have little or no voice in the international political debate [28].

Schlosberg [25] argues that the concept of environmental justice has broadened from notions of landscapes and biodiversity to include where people "live, work and play" (p. 39). This iconic phrase to describe the environment as "where we live, work and play" (p. 328) was first used in 1997 and later applied to policy and planning of just sustainable communities where greenspace plays a critical role [28]. Boone and colleagues [10] describe several aspects of environmental justice around greenspace that include park design, which may favor the desired uses of certain elites (usually white males); the need to include minorities in the decision-making processes (procedural equity); the important leadership role of non-governmental organizations (NGOs) in funding, implementing and maintaining parks; and the critical tension between maintenance vs. neglect of parks that define whether parks are a good (amenity) or a bad (dangerous) place for the community.

To better understand the different aspects of environmental justice, both Agyeman et al. [28] and Walker [12] conceptualize justice as a trivalent concept that includes distributive, procedural and recognition-based justice. According to Walker [12] (p. 42), distributive justice refers to "who gets what in the environment" or who receives the environmental burdens or benefits, with important implications on the spatial and temporal definitions of the affected groups. For example, spatial implications are evident in international boundaries where indigenous peoples have historically crossed; and temporal implications could refer to future generations. Procedural justice, Walker [12] (p. 47) states, refers to "why things are how they are" and "how things should be" and acknowledges the institutional contexts that allow distributive injustices to occur, calling for an inclusive decision-making process. Justice as recognition is deeply related to procedural and distributive justice and refers to the devaluation, stigmatization, and other practices that are linked to oppression and cultural domination. In the case of recognition, its scope expands beyond racism and other "isms" to include multiple identity dimensions including gender and disability $[12,28]$. To understand the links between these dimensions, it is necessary to examine who wins and who loses, or whose rights are being overlooked and who or what is responsible (rights and responsibilities) [29].

The framework set out by Bulkeley et al. [24], for climate justice incorporates these elements of rights and responsibilities along with the elements of distribution, procedure, and recognition. The authors also stress the importance of considering the multiple actors involved in environmental justice in cities that include individuals, communities, governments, private sectors, and NGOs. Just like environmental justice theorists have highlighted recognition as a critical dimension for analyzing distributive and procedural justice, so are questions on rights and responsibilities—or who wins and who loses. Here, we integrate across these diverse aspects of environmental justice around greenspace to better understand the complexity of the forces that drive the social production of unjust cities.

\section{Our Approach}

Because greenspacejustice is a new and emergent topic studied from a variety of disciplines, we conducted an integrative review to analyze the ways in which researchers from different disciplinary perspectives understand greenspace justice issues. Integrative reviews are conducted to undertake interdisciplinary discussions addressing both emergent and mature topics [30]. We draw from MacBride-Steward and Antell's [13] integrative literature review on nature, gender, and health, where the authors selected studies from 
a number of disciplines (e.g., sociology, psychology, geography, health, environmental science, epidemiology, public health) by conducting searches using relevant key words and identifying relevant papers based on the titles and abstracts.

A such, we initially identified a list of studies using the search engine Web of Science. Following Hartig and colleagues' [9] suggestion to use multiple terms around greenspace or nature in literature searches, we used the parameters "greenspace, green infrastructure, green space, parks, trees, greenways, sport fields, gardens, landscapes, nature, OR trees;" AND parameters around "environmental justice, equity, OR equality;" AND "urban." For our selection, we focused on peer-reviewed English-language articles from the time period between 2012 and 2018 to capture recent trends in scholarly activity. We screened the first 50 articles of each search sorted by relevance and obtained a total of 161 articles.

To determine the main discipline of the articles, we followed the methodology set out by Boulton et al. [31] and looked at the Subject Classification of the journal. We used Ulrichsweb Global Serials Directory to obtain the subject of the studies. We found that often times, journals list several subject classifications, many of which include "environmental studies" $(n=79)$. To unveil the diversity of subjects in these cases, we classified the articles with multiple subjects according to a subject other than environmental studies. Overall, we found 27 different subject classifications listed in Table 1. The most frequent subject classifications were environmental studies, urban planning, conservation, forestry, public health, and geography.

Table 1. Subject classifications and articles identified in search.

\begin{tabular}{cc}
\hline Subject Classification & Number of Articles \\
\hline Agriculture & 1 \\
Anthropology & 1 \\
Architecture & 1 \\
Construction & 1 \\
Comprehensive works & 3 \\
Computer applications & 1 \\
Conservation & 25 \\
Education & 1 \\
Energy & 1 \\
Environmental studies & 30 \\
Forestry & 17 \\
Gardening & 3 \\
Geography & 13 \\
Geology & 1 \\
Law & 2 \\
Meteorology & 1 \\
Photography & 1 \\
Political science & 1 \\
Psychology & 3 \\
Public administration & 4 \\
Public health & 16 \\
Recreation & 3 \\
Social services & 2 \\
Sociology & 1 \\
Tourism & 1 \\
Urban planning & 26 \\
Women's studies & 1 \\
Total & \\
\hline & 161 \\
\hline &
\end{tabular}

We screened the titles and abstracts of studies from the most frequent subjects to identify the ones directed to inform different disciplines, or the work of professionals that influence the built environment in some way (e.g., public health, urban planning, urban forestry, landscape architecture, park management, water management, and conservation of biodiversity). We selected 21 papers to 
represent not only the different disciplines, but also a range of geographic locations (Canada, U.S., Latin America, Europe, Africa, Asia, and Oceania), as well as a variety of methodologies and theoretical approaches (Table 2).

Table 2. Selected papers for this review.

\begin{tabular}{|c|c|c|c|c|}
\hline Disciplines & Paper & $\begin{array}{l}\text { Theories (Other Than } \\
\text { Environmental Justice) }\end{array}$ & Methodology & $\begin{array}{l}\text { Geographic } \\
\text { Location }\end{array}$ \\
\hline \multirow{3}{*}{ Public health } & {$[32]$} & $\begin{array}{l}\text { Environmental } \\
\text { psychology }\end{array}$ & $\begin{array}{c}\text { Conduct analysis } \\
\text { between survey results } \\
\text { and geospatial data }\end{array}$ & Tehran, Iran \\
\hline & [33] & $\begin{array}{c}\text { Climate change } \\
\text { adaptation, ecosystem } \\
\text { services }\end{array}$ & $\begin{array}{l}\text { Model access to green } \\
\text { space and its relationship } \\
\text { with deprivation, } \\
\text { density, gender and age }\end{array}$ & $\begin{array}{l}\text { Montreal and } \\
\text { Quebec, Canada }\end{array}$ \\
\hline & [34] & $\begin{array}{l}\text { Environmental policy, } \\
\text { epidemiology }\end{array}$ & $\begin{array}{l}\text { Propose the Green } \\
\text { Gentrification and } \\
\text { Health Equity model }\end{array}$ & North America \\
\hline \multirow{3}{*}{ Urban planning } & [35] & $\begin{array}{c}\text { Sustainability, resilience, } \\
\text { ecosystem services, food } \\
\text { security }\end{array}$ & $\begin{array}{l}\text { Spatial and temporal } \\
\text { analysis (land use-land } \\
\text { cover change) using } \\
\text { remote sensing images }\end{array}$ & Kumasi, Ghana \\
\hline & [36] & $\begin{array}{l}\text { Ecosystem services, } \\
\text { urban resilience }\end{array}$ & $\begin{array}{c}\text { Conduct an in-depth } \\
\text { analysis to develop a } \\
\text { new agenda for research }\end{array}$ & European cities \\
\hline & [37] & Ecosystem services & $\begin{array}{c}\text { Synthesize } \\
\text { Anglo-American } \\
\text { research and compare to } \\
\text { a case in China }\end{array}$ & Hangzhou, China \\
\hline \multirow{3}{*}{ Urban forestry } & [38] & Ecosystem services & $\begin{array}{c}\text { Estimates greenery } \\
\text { coverage with aerial } \\
\text { imagery and } \\
\text { socioeconomic and land } \\
\text { use data }\end{array}$ & $\begin{array}{c}\text { Portland-Vancouver, } \\
\text { US }\end{array}$ \\
\hline & [39] & Urban resilience & $\begin{array}{c}\text { Conduct spatial analysis } \\
\text { of land cover data and } \\
\text { census data across } 7 \text { US } \\
\text { cities }\end{array}$ & $\begin{array}{c}\text { Seven cities in the } \\
\text { US }\end{array}$ \\
\hline & [40] & Ecosystem services & $\begin{array}{c}\text { Analyze geospatial tree } \\
\text { distribution and } \\
\text { socioeconomic data }\end{array}$ & Bogota, Colombia \\
\hline \multirow{3}{*}{$\begin{array}{l}\text { Landscape } \\
\text { architecture }\end{array}$} & [41] & $\begin{array}{l}\text { Geographical } \\
\text { imagination }\end{array}$ & $\begin{array}{l}\text { Analyze of the history of } \\
\text { park design movements } \\
\text { in the US }\end{array}$ & Parks in the US \\
\hline & [42] & Political ecology & $\begin{array}{l}\text { Explore the history and } \\
\text { architecture of parks in } \\
\text { the context of } \\
\text { city-making }\end{array}$ & $\begin{array}{l}\text { Vijalpore, Gujarat, } \\
\text { India }\end{array}$ \\
\hline & [43] & $\begin{array}{l}\text { Urban planning, urban } \\
\text { design }\end{array}$ & $\begin{array}{l}\text { Analyze urban forest } \\
\text { change through archive } \\
\text { records and aerial } \\
\text { photography }\end{array}$ & $\begin{array}{l}\text { University of } \\
\text { Pennsylvania, } \\
\text { Philadelphia, US }\end{array}$ \\
\hline
\end{tabular}


Table 2. Cont.

\begin{tabular}{|c|c|c|c|c|}
\hline Disciplines & Paper & $\begin{array}{l}\text { Theories (Other Than } \\
\text { Environmental Justice) }\end{array}$ & Methodology & $\begin{array}{l}\text { Geographic } \\
\text { Location }\end{array}$ \\
\hline \multirow{3}{*}{$\begin{array}{c}\text { Park } \\
\text { management }\end{array}$} & {$[44]$} & Sustainable development & $\begin{array}{l}\text { Examine of } \\
\text { neighborhood park } \\
\text { conditions and survey } \\
\text { responses on park use } \\
\text { from children }\end{array}$ & $\begin{array}{c}\text { Cape Town, South } \\
\text { Africa }\end{array}$ \\
\hline & {$[45]$} & $\begin{array}{l}\text { Ecosystem services, } \\
\text { sustainable development }\end{array}$ & $\begin{array}{l}\text { Conduct spatial analyses } \\
\text { and modeling using } \\
\text { graphic data and census } \\
\text { data }\end{array}$ & Changting, China \\
\hline & {$[46]$} & Urban planning & $\begin{array}{l}\text { Employs ordinary least } \\
\text { squares models to } \\
\text { examine social equity of } \\
\text { each greenspace type }\end{array}$ & Brisbane, Australia \\
\hline \multirow{3}{*}{$\begin{array}{c}\text { Water } \\
\text { management }\end{array}$} & [47] & Sustainability & $\begin{array}{c}\text { Profiling of program } \\
\text { objectives (policies, } \\
\text { documents) and design } \\
\text { features of alley greening } \\
\text { programs }\end{array}$ & $\begin{array}{l}\text { Seven cities in the } \\
\text { US }\end{array}$ \\
\hline & {$[48]$} & Water security & $\begin{array}{c}\text { Develop a green } \\
\text { infrastructure equity } \\
\text { index as a planning tool } \\
\text { to prioritize projects }\end{array}$ & $\begin{array}{l}\text { Melbourne, } \\
\text { Australia }\end{array}$ \\
\hline & [49] & Water security & $\begin{array}{l}\text { Examine factors that } \\
\text { influence the variability } \\
\text { in distribution of green } \\
\text { infrastructure projects }\end{array}$ & $\begin{array}{l}\text { Philadelphia, PA, } \\
\text { USA }\end{array}$ \\
\hline \multirow{3}{*}{$\begin{array}{l}\text { Conservation of } \\
\text { biodiversity }\end{array}$} & {$[50]$} & Ecosystem services & $\begin{array}{l}\text { Examine of bird } \\
\text { communities in small } \\
\text { greening projects }\end{array}$ & Boston, MA, USA \\
\hline & [51] & $\begin{array}{c}\text { Sustainability, ecosystem } \\
\text { services }\end{array}$ & $\begin{array}{l}\text { Compare spatial patters } \\
\text { between semi-natural } \\
\text { spaces, urban landscapes } \\
\text { and socioeconomic data }\end{array}$ & Paris, France \\
\hline & [52] & $\begin{array}{c}\text { Climate change } \\
\text { adaptation, urban } \\
\text { climate justice, } \\
\text { sustainability, ecosystem } \\
\text { services }\end{array}$ & $\begin{array}{l}\text { Propose a framework to } \\
\text { examine the links } \\
\text { between human and } \\
\text { non-human phenomena } \\
\text { of urban climate justice }\end{array}$ & No specific location \\
\hline
\end{tabular}

Note: Theories in italics show inferred theoretical frameworks, not explicit in the cases.

The cases examined here illustrate a diversity of approaches to analyze environmental justice issues around greenspace to help us integrate scholarly trends and patterns. Although many cases frame the study from the perspective of multiple disciplines (e.g., urban planning and public health [34], biodiversity conservation and landscape design [51]), we categorized the cases according to the most dominant argument in the paper. This diversity in lenses in which these environmental issues are explored is also evident in the wide breath of journals that publish these types of studies.

We observe that scholars who write about greenspace justice usually engage with a diverse set of theories including environmental psychology, climate change adaptation and resilience, ecosystem services, political ecology, sustainable development, geographical imagination, water security, and landscape connectivity. Methodologies employed in the cases studied here also show a wide diversity that range from quantitative analysis (usually employed through geographic information systems, using remote sensing 
images and census data) to participatory methodologies (such as surveys and interviews), as well as in-depth qualitative analysis of historic and other types of documents. Our sample of papers also includes studies that propose theoretical frameworks and models to help analyze and diagnose environmental justice issues.

To better understand environmental justice in greenspace across these cases, we adopt the framework developed by Bulkeley et al. [24], which frames justice broadly as a multidimensional concept integrated by (1) distribution (who gets what); (2) procedures (why things are the way they are); (3) rights (who loses); (4) responsibilities (who or what is responsible for the injustices); and (5) recognition (the cultural and oppressive practices that allow injustice). For environmental justice to be analyzed at the urban scale, Bulkeley et al. [24] recommend researchers and practitioners study justice as a multivalent concept based on recognition because it is necessary to recognize justice in all facets of environmental justice to examine which are overlooked or downplayed.

\section{Results}

\subsection{Recognition}

Recognition calls attention to the "cultural and symbolic injustices" that prevent certain groups to be considered [24] (p. 33). According to Bulkeley et al. [24], recognition means being aware of not only of the responsibilities and the needs of certain populations, but also of how both the practice and politics of certain actions affects justice. In this section, we analyze the various definitions used for greenspace justice, including equity and equality and the narratives employed to support the importance of these issues.

We observe that many authors define justice, or its corollary concepts of inequality and inequity, in terms of the equal distribution of its benefits among all groups of urban residents [35,37,38,40,45]. Some studies go beyond this spatial notion of justice to include time. For instance, when green intervention projects intended to revitalize a low-income neighborhood result in gentrification that displaces poor people away from this area, thus perpetuating the problem [34,36,43], or when it affects future generations [45]. In addition, some studies also define justice in procedural terms that include notions of inclusion in decision-making processes [36], maintenance [39], policies and design features [47,52], and need-based approaches [48].

In terms of the narratives used to explain the importance of justice in greenspace, we found that most researchers frame justice concerns from an ethical and fairness perspective [34,39-41,45,46,52]. However, we identified variation based on the disciplinary perspective. For example, for public health researchers, greenspace justice is important because it is linked to the wellbeing of the residents [32-34]. For urban planning scholars, greenspace justice is important for democratic reasons-greenspace is funded by public institutions and all citizens should enjoy the benefits [36], and because it is related to SDG 11, as our case from Ghana portrays [35]. Urban foresters call for greenspace justice because the ecosystem services provided by trees should be available to all [38-40]. For landscape architects, the importance of greenspace justice relies on the core purpose of parks, which is to provide recreational places for all [41], and because parks contribute to the division of societies, as our case from India suggests [42]. Park managers consider greenspace justice important because parks are public facilities that should serve everyone, comparable to schools, libraries, and museums [45]. Water managers offer more pragmatic reasons for addressing justice issues including the need to increase the efficiency of distributed stormwater management systems [48]; the need to include alleys as significant public infrastructure resources [47]; and to comply with regulations on water quality and flows [49]. Finally, conservationists look at the larger landscape connectivity challenge arguing that greenspace justice is needed to protect and support biodiversity and allow greenspace connectivity across entire landscapes [50-52]. 


\subsection{Distribution and Procedures}

Distribution refers to the uneven distribution of the benefits of greenspace-or who gets what in the environment-with spatial and temporal implications. Procedures refers to the institutional contexts that allow distributive injustices to occur-or why things are the way they are. In this section, we examine the way researchers operationalize the concept of greenspace justice in their studies to differentiate between distribution or procedural justice by field of study (Table 3).

Our analysis of distribution and procedural justice supports the assumption that justice in distribution of greenspace is the most common notion of greenspace justice. In addition, our findings suggest that the disciplinary lens used to examine greenspace justice affects the type of justice portrayed in the study. For example, urban foresters concentrate on the spatial distribution of the issue [38-40], with some attention to temporal distribution [39]. Similarly, public health researchers explore these issues mostly in terms of distribution, both with a spatial focus [32], temporal [34], or with both a spatial and temporal focus [33]. In contrast, our sample of landscape architect research looks at greenspace justice exclusively from a procedures' perspective, mostly in hindsight, including the examination of social processes that were used in park design [41], politics and ideologies behind the creation of parks [42], and historic analysis of narratives [43].

Other disciplines look at both types of justice. For example, park managers examine the spatial distribution of greenspace $[45,46]$, with some attention to community participation, which corresponds to procedural justice [44]. Also, urban planners examine justice mostly in terms of distribution, both spatial and temporal [35-37] with some procedural focus on decision-making and power asymmetries [37]. Similarly, conservationists explore justice mostly in terms of spatial distribution [50,51], with some extension to its legal implications [52]. Finally, similar to recognition, water managers are the most diverse discipline in terms of their analysis of justice. They either focus on the spatial distribution of green infrastructure projects [48], the procedural lens of program objectives and features [47], or all the types of justice-spatial and temporal distribution, as well as procedural by looking at collaborative processes [49].

In terms of spatial distribution, we found that periurban areas are critical, with both positive and negative outcomes. In our cases in China and the U.S. [37,45], periurban areas are considered areas that typically benefit from greenspace, as opposed to the urban core. However, these trends are changing in some cities in the U.S. as whites are moving to the urban core [37]. In other cases, periurban areas are deprived of vegetation, as can be seen in the cases from Bogota, Colombia [40], Cape Town, South Africa [44], and Vijalpore, India [42]. Finally, there are situations in which periurban areas are both beneficiaries of the distribution of greenspace as well as areas deprived of vegetation, as the case of Kumasi, Ghana suggests [35].

Another important element of justice in the spatial distribution of greenspace from the perspective of different disciplines is the size of greenspace. The cases analyzed here suggest that the limited benefits of small size greenspace increase through connectivity, that is, if the small size greenspace is connected to a larger greenspace network, as seen by public health researchers [33], recreation (walking and biking paths) from the perspective of park management researchers [45], and urban biodiversity (connecting habitat patches) [50]. 
Table 3. Operationalization of greenspace justice and its relationship with distribution and procedural justice.

\begin{tabular}{|c|c|c|c|c|c|}
\hline \multirow{2}{*}{ Disciplines } & \multirow{2}{*}{ Paper } & \multirow{2}{*}{ How is Greenspace Justice Operationalized? } & \multicolumn{2}{|c|}{ Distribution } & \multirow[t]{2}{*}{ Procedure } \\
\hline & & & Spatial & Temporal & \\
\hline \multirow{3}{*}{ Public health } & [32] & $\begin{array}{l}\text { Percentage of greenspace area in a neighborhood and its relation to } \\
\text { socioeconomic, crime, and wellbeing data }\end{array}$ & $x$ & & \\
\hline & [33] & $\begin{array}{l}\text { Proximity of individuals to closest greenspace boundary using } \\
\text { travel costs and spatial interaction models, on a chronological basis }\end{array}$ & $\mathrm{X}$ & $\mathrm{x}$ & \\
\hline & [34] & $\begin{array}{l}\text { "The role of gentrification in mediating the relationship between } \\
\text { green space and health outcomes" (p. 1120) }\end{array}$ & & $X$ & \\
\hline \multirow{3}{*}{ Urban planning } & [35] & $\begin{array}{c}\text { Proportion of vegetation cover and percentage change in } \\
\text { vegetation cover }\end{array}$ & $\mathrm{X}$ & $x$ & \\
\hline & [36] & “(D)istribution, procedures, recognition and capabilities" (p. 124) & $\mathrm{X}$ & $x$ & $\begin{array}{l}\text { Decision-making processes, power } \\
\text { asymmetries, privatization of greenspace }\end{array}$ \\
\hline & [37] & $\begin{array}{c}\text { Access to urban greenspace, park size, park service area, park } \\
\text { quality, facilities, perceived safety, organized recreation, } \\
\text { gentrification }\end{array}$ & $X$ & $X$ & \\
\hline \multirow{3}{*}{ Urban forestry } & [38] & $\begin{array}{c}\text { Access to greenspace }=\text { average Euclidean distance between block } \\
\text { group centroid and greenspace }\end{array}$ & $X$ & & \\
\hline & [39] & Distribution of urban tree canopy and census data & $x$ & $x$ & \\
\hline & [40] & $\begin{array}{l}\text { Analyzed tree inventory-taxonomy, structure, attributes and } \\
\text { condition of trees—and potential ecosystem services with } \\
\text { socioeconomic data }\end{array}$ & $x$ & & \\
\hline \multirow{3}{*}{$\begin{array}{l}\text { Landscape } \\
\text { architecture }\end{array}$} & [41] & $\begin{array}{l}\text { Historic analysis of the relationship between parks and social } \\
\text { processes in park design }\end{array}$ & & & $\begin{array}{l}\text { The imaginary of space-the role of social } \\
\text { issues in park design }\end{array}$ \\
\hline & [42] & $\begin{array}{l}\text { Analysis of parks as political and ideological projects in the context } \\
\text { of city-making }\end{array}$ & & & $\begin{array}{l}\text { The elite's values behind the creation of } \\
\text { parks; the process of park creation involves } \\
\text { displacement of the poor; naming of the } \\
\text { park }\end{array}$ \\
\hline & {$[43]$} & $\begin{array}{l}\text { Chronological analysis of tree cover and the historic narratives } \\
\text { used in each time period }\end{array}$ & & & Landscape design principles \\
\hline
\end{tabular}


Table 3. Cont.

\begin{tabular}{|c|c|c|c|c|c|}
\hline \multirow{2}{*}{ Disciplines } & \multirow{2}{*}{ Paper } & \multirow{2}{*}{ How is Greenspace Justice Operationalized? } & \multicolumn{2}{|c|}{ Distribution } & \multirow[t]{2}{*}{ Procedure } \\
\hline & & & Spatial & Temporal & \\
\hline \multirow{3}{*}{ Park management } & [44] & $\begin{array}{l}\text { Use patterns of community neighborhood park in relation to travel } \\
\text { time to access the park }\end{array}$ & $x$ & & Community participation \\
\hline & [45] & Layout of urban public parks & $x$ & $x$ & \\
\hline & [46] & $\begin{array}{l}\text { Provision, accessibility, and population pressure according to } \\
\text { greenspace type }\end{array}$ & $x$ & & \\
\hline \multirow{3}{*}{$\begin{array}{c}\text { Water } \\
\text { management }\end{array}$} & [47] & $\begin{array}{c}\text { Green alley program goals and practices in terms of sustainability } \\
\text { (environment, economic, equity) }\end{array}$ & & & Program objectives and design features \\
\hline & [48] & $\begin{array}{l}\text { Equity voids are identified through (1) socioeconomic variables } \\
\text { (disadvantage and vulnerability) and (2) environmental factors } \\
\text { (exposure to risks and access to amenities) }\end{array}$ & $\mathrm{X}$ & & \\
\hline & [49] & $\begin{array}{l}\text { Spatial variability in the distribution of green stormwater } \\
\text { infrastructure investment (public and private) }\end{array}$ & $x$ & $x$ & $\begin{array}{l}\text { Community capacity, collaborative } \\
\text { approaches }\end{array}$ \\
\hline \multirow{3}{*}{$\begin{array}{l}\text { Conservation of } \\
\text { biodiversity }\end{array}$} & [50] & $\begin{array}{c}\text { Size —small vs. large —of greening projects and its relationship } \\
\text { with species richness }\end{array}$ & $\mathrm{X}$ & & \\
\hline & [51] & $\begin{array}{l}\text { Spatial organization of public semi-natural spaces and its } \\
\text { features-biological traits and biodiversity }\end{array}$ & $X$ & & \\
\hline & [52] & Vulnerability to climate change of non-human species & $x$ & & $\begin{array}{l}\text { Wild law-policies that include the rights } \\
\text { of non-human-nature }\end{array}$ \\
\hline
\end{tabular}


Interestingly, cases across multiple disciplines suggest that not all greenspace is even desired. From research on urban planning, we found that the shape and location of greenspace may be problematic (e.g., parks beneath freeways and elongated parks along main road) because of issues related to pollution [37] and that privileged people sometimes prefer not to have vegetation for safety reasons, like our case from Kumasi, Ghana demonstrates [35]. Here, wealthy people avoid vegetation because it serves as habitat for scorpions, snakes, and other animals, and as a hideout for criminals. Similarly, cases from urban forestry research show that some people do not like trees because they demand resources (water), can foster crime, may produce allergens, may be pollution precursors, can damage infrastructure, litter, and entail maintenance costs [39,40]. Even biodiversity conservation researchers acknowledge that not everyone considers greenspace desirable, and that residents' perceptions of greenspace depend on their behavior, the type of district and socioeconomic profile [51].

Maintenance emerged as a critical factor in greenspace justice related to safety from the perspective of several disciplines. Water management researchers show that some communities may prefer greenspace that does not portray a "wild" aspect for safety concerns [48] (p. 269). Justice issues emerge when people who struggle financially may not be able to commit to maintaining greenspace in the long term. Landscape architecture researchers also indicate that lack of maintenance leads to spaces that foster crime [41]. Similarly, park management researchers argue that detrimental greenspace may discourage residents to use it and act as its guardians, resulting in safety issues [46], or simply that appalling conditions of parks do not attract users [44]. Likewise, urban forestry researchers indicate that increased vegetation may be perceived as neglected areas that foster crime, particularly in cities located in humid climates [39].

Another common concern relates to the temporal distribution of greenspace justice-gentrification. Often times, public health practitioners and researchers from multiple disciplines call for greening interventions without considering the socio-spatial dynamics that may trigger new environmental justice issues. According to Cole et al. [34] from public health research, green intervention projects have the objective of improving human health, but paradoxically, gentrification processes lead to lower levels of health in low income and minority populations, as they suffer stress from the increasing cost of living, displacement, and a change in social environments. From urban planning research, Wolch et al. [37] argue that it is important to develop greening projects that are "just green enough"' so that residents experience some contact with nature and its health benefits without getting displaced. Park management research also mentions gentrification as a negative externality of new parks [45]. Urban forestry research shows opposing arguments in this topic. Some urban forestry researchers acknowledge gentrification issues of tree planting initiatives [39]; while others consider premium in property values as a benefit of trees [40]. Related to gentrification, water management research found that land tenure plays a major role in greenspace equity issues-people are less likely to implement greening projects when they do not own their property, or when they have smaller properties and therefore less space for greenspace [48].

Our analysis of landscape architecture research unveiled subtle park features that may result in justice issues, which were not highlighted in studies from other disciplines. According to Larson [41] and Zimmer et al. [42], park design that fosters certain uses reflects the desired behavior of privileged social groups. In addition, the creation of parks itself involves injustice because often times the poor are displaced to give room for the beautification project [42]. Park rules may discriminate certain groups of people (e.g., no skating, rollerblading, dogs, picnics, no-sleeping benches) reinforced by the presence of security officers, and safety features (cameras). Programming of activities in greenspace may favor certain groups over others, which usually are those that attract money (tourists) [41]. In other cases, parks are created to attract foreign investment [42]. Finally, landscape design that is directed inward excludes certain groups from using greenspace (e.g., fences, gates, shrubs, building orientation) [43]. 


\subsection{Rights and Responsibilities}

Rights refers to the group of people whose rights are overlooked in greenspace justice (who loses); while responsibilities refer to the processes, policies, organizations, or groups that are responsible for the injustice. In this final section, we examine the way researchers from several disciplines identify the population groups affected by greenspace injustice (Table 4). We also explore the reasons behind the injustices as well as the solutions offered to achieve more just cities.

In terms of rights, we found that all researchers consider low-income people as the population group whose rights of greenspace are being overlooked or ignored (Table 4). Likewise, racial minorities, or non-whites [44], lower caste [42], and people with different cultural backgrounds and religions [36] were identified as the targeted group of greenspace injustice for most disciplines, except conservation of biodiversity. Related to racial minorities, immigrants are identified by many disciplines, including urban planning [36], urban forestry [40], landscape architecture [42], and park management [44,45]. Similarly, gender issues are seen as critical in greenspace justice, including public health, urban planning, park management, and conservation of biodiversity. In this case, females are the vulnerable group, particularly when there are safety concerns in greenspace [32]. Another vulnerable group seen as overlooked in greenspace justice is people who live in high-density neighborhoods, including public health, urban forestry, water management, and conservation of biodiversity. Living in high-density neighborhoods does not necessarily mean that people are poor, as the case in Paris suggests [51]. In addition, land tenure is a common factor examined in many disciplines, including urban forestry [39], park management [45], and water management [48]. Finally, groups related to age (elderly, youth, and children) are highlighted by most sets of researchers as underserved in terms of greenspace, except for our sample of landscape architecture, urban forestry, and water management research.

We found other groups disproportionately affected by greenspace justice issues. For example, educational level and people living in cities in arid climates are disproportionately affected when comparing them to humid climates as identified by urban forestry researchers [38,39]. Our sample of park management research added more underserved groups to the list including disabled people [45], lonely people [44], people living beyond a 15 minute walk to a greenspace [44,45], unemployed and retired people, and future generations [45]. Water management researchers identified people living in neighborhoods prone to flooding [47], and people who do not participate in community engagement initiatives [48]. Non-human species group, or nature, is highlighted as underserved in greenspace justice by conservation of biodiversity researchers [52].

Surprisingly, our analysis suggests that groups likely related to a particular discipline were not acknowledged in our sample studies. For example, our sample of urban planning research does not mention groups affected by planning issues, such as renters, people living in high-density neighborhoods, people who do not participate in community initiatives, and people living beyond a 15 min walk to a greenspace. Similarly, our sample from landscape architecture research does not acknowledge people who are typically considered in park design, such as people living in flooding areas, vulnerable ages (elderly, youth, children), females, disabled, lonely people, and non-human species. This finding suggests that interdisciplinary research is needed to improve individual professional practices. 
Table 4. Groups of people whose rights are overlooked in greenspace justice according to each discipline.

\begin{tabular}{|c|c|c|c|c|c|c|c|c|c|c|c|c|c|c|c|c|c|c|c|c|}
\hline 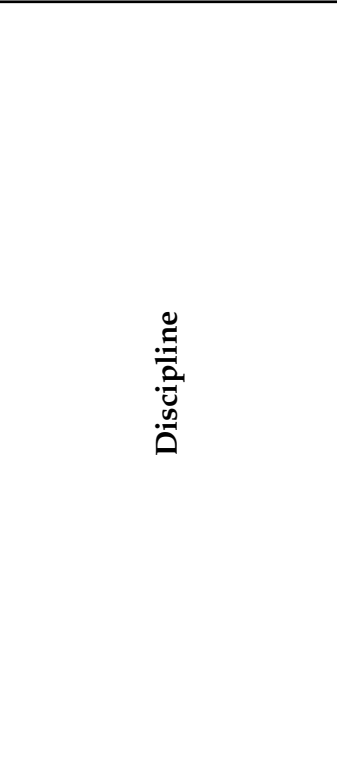 & $\begin{array}{l}\bar{\Xi} \\
\stackrel{0}{0}\end{array}$ & 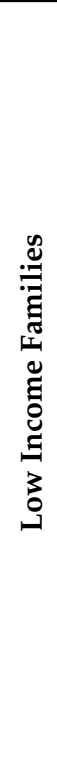 & 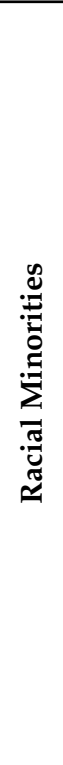 & 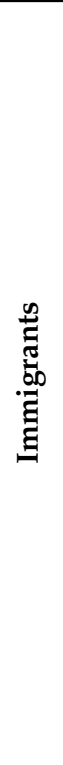 & 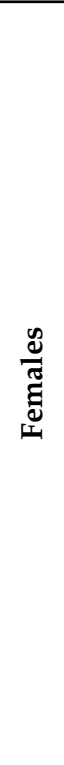 & $\frac{\lambda}{\frac{d}{0}}$ & $\stackrel{D}{\vec{z}}$ & 窇 & 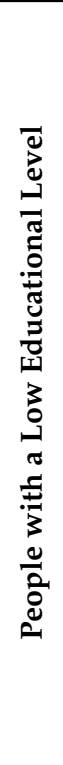 & 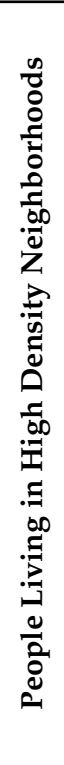 & & $\begin{array}{l}\stackrel{0}{0} \\
0 \\
0 \\
0 \\
0 \\
0 \\
0 \\
0 \\
0 \\
0\end{array}$ & 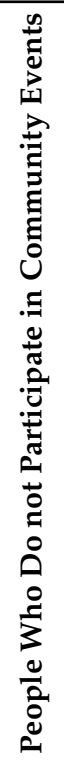 & 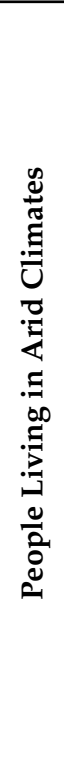 & 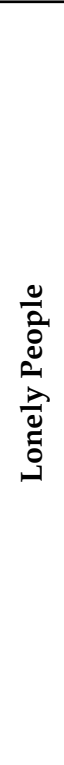 & 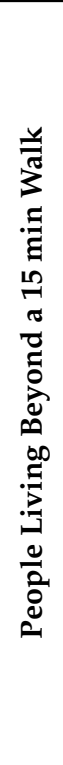 & 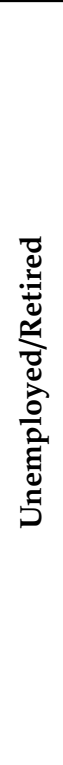 & 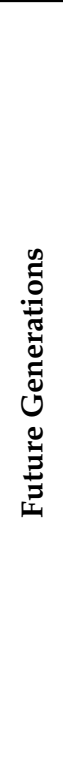 & 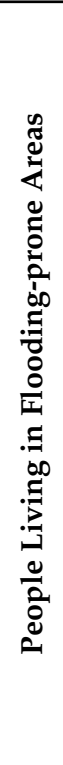 & 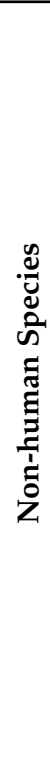 \\
\hline & [32] & & & & $\mathrm{X}$ & & & & & & & & & & & & & & & \\
\hline \multirow[t]{3}{*}{ Public health } & [33] & $x$ & & & & $x$ & & & & $x$ & & & & & & & & & & \\
\hline & [34] & $x$ & $\mathrm{X}$ & & & & & & & & & & & & & & & & & \\
\hline & [35] & $\mathrm{X}$ & & & & $x$ & $\mathrm{X}$ & $x$ & & & & & & & & & & & & \\
\hline \multirow[t]{3}{*}{ Urban planning } & [36] & $\mathrm{x}$ & $X$ & $X$ & $X$ & $\mathrm{X}$ & & & & & & & & & & & & & & \\
\hline & [37] & $\mathrm{x}$ & & & $X$ & & & & & & & & & & & & & & & \\
\hline & {$[38]$} & & & & & & & & $x$ & $x$ & & & & & & & & & & \\
\hline \multirow[t]{3}{*}{ Urban forestry } & [39] & $\mathrm{X}$ & $X$ & & & & & & $X$ & & $X$ & & & $X$ & & & & & & \\
\hline & [40] & $\mathrm{X}$ & & $\mathrm{X}$ & & & & & & $x$ & & & & & & & & & & \\
\hline & [41] & $\mathrm{x}$ & $X$ & & & & & & & & & & & & & & & & & \\
\hline \multirow[t]{2}{*}{ Landscape architecture } & [42] & $\mathrm{X}$ & & $X$ & & & & & & & & & & & & & & & & \\
\hline & [43] & $\mathrm{X}$ & $X$ & & & & & & & & & & & & & & & & & \\
\hline
\end{tabular}


Table 4. Cont.

\begin{tabular}{|c|c|c|c|c|c|c|c|c|c|c|c|c|c|c|c|c|c|c|c|c|}
\hline 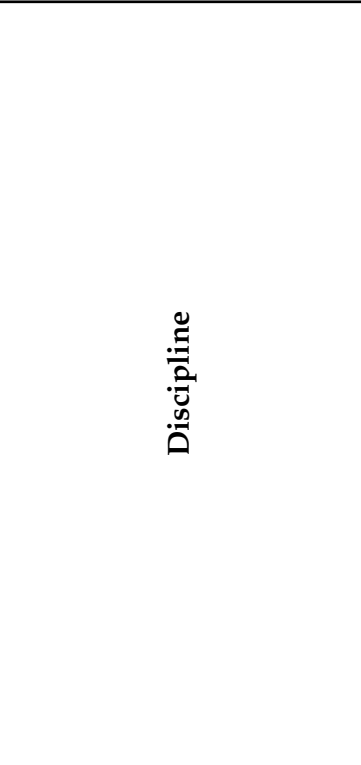 & $\begin{array}{l}\grave{\Xi} \\
\stackrel{a}{\sigma}\end{array}$ & 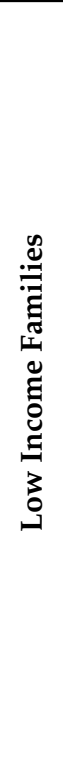 & 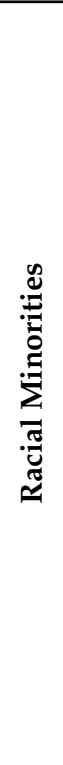 & 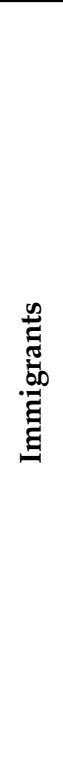 & 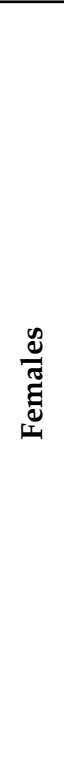 & $\frac{\lambda}{\frac{d}{d}}$ & $\stackrel{5}{\Xi}$ & 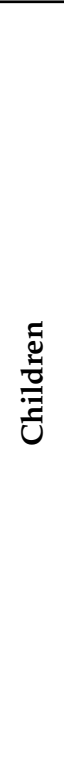 & 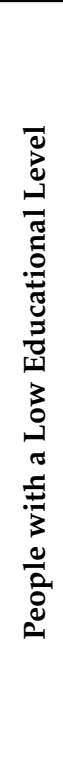 & 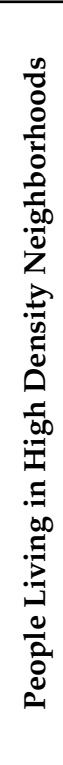 & $\frac{\infty}{\stackrel{0}{d ~}}$ & $\begin{array}{l}\frac{0}{2} \\
0 \\
0 \\
0 \\
0 \\
0 \\
0 \\
0 \\
0\end{array}$ & 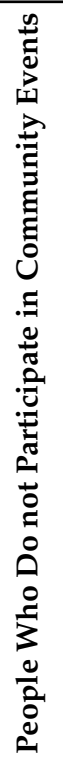 & 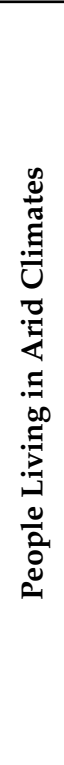 & 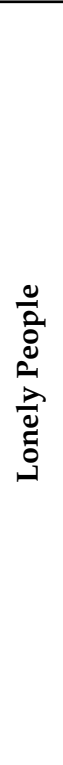 & 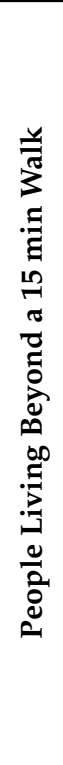 & 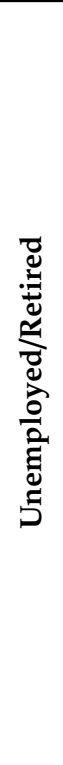 & 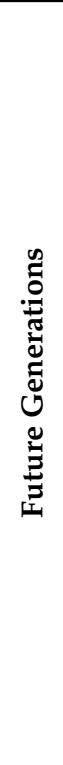 & 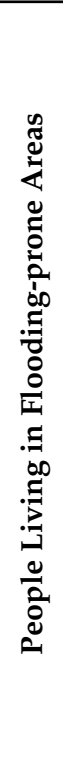 & 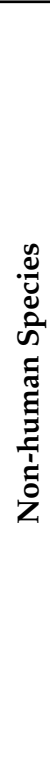 \\
\hline & [44] & $\mathrm{X}$ & $\mathrm{X}$ & $X$ & $X$ & & & & & & & & & & $\mathrm{X}$ & $X$ & & & & \\
\hline \multirow[t]{3}{*}{ Park management } & [45] & & & $\mathbf{X}$ & $X$ & $X$ & & $X$ & & & $\mathrm{X}$ & $X$ & & & & $X$ & $X$ & $X$ & & \\
\hline & [46] & $\mathrm{X}$ & & & & & & $X$ & & & & & & & & & & & & \\
\hline & [47] & $\mathrm{X}$ & & & & & & & & & & & & & & & & & $x$ & \\
\hline \multirow[t]{3}{*}{ Water management } & [48] & $\mathrm{X}$ & $\mathrm{X}$ & & & & & & & $x$ & $x$ & & $\mathrm{X}$ & & & & & & & \\
\hline & [49] & $\mathrm{X}$ & $X$ & & & & & & & & & & & & & & & & & \\
\hline & {$[50]$} & $\mathrm{X}$ & & & & & & & & $X$ & & & & & & & & & & \\
\hline \multirow[t]{2}{*}{ Biodiversity conservation } & {$[51]$} & $X$ & & & & & & & & & & & & & & & & & & \\
\hline & [52] & $X$ & & & $\mathrm{X}$ & $X$ & & $X$ & & & & & & & & & & & & $\mathrm{X}$ \\
\hline
\end{tabular}


Regarding responsibilities, our sample of research finds responsibilities for greenspace injustice that transcend individual disciplinary boundaries. Urban planning researchers, for example, acknowledge that justice issues are in part a consequence of urbanization, lack of city planning and institutional failures, as our case from Kumasi, Ghana illustrates [35]. Urban planning researchers also highlight how greenspace privatization and power dynamics in government processes enable injustice [36], as well as land use zoning [37]. However, this disciplinary approach to environmental justice also finds responsibilities in landscape architects and ecologists, who should work with stakeholders to address their needs in the creation of greenspace [37]; and in park management for greenspace neglect [35]. Similarly, researchers from landscape architecture acknowledge that park design contributes to greenspace injustice, but the responsibility also falls in park managers in terms of park rules and programming of activities [41], and urban planners in terms of philosophical movements, mortgage assistant programs available to selected groups, and government turnover [43].

Interestingly, all of the disciplines analyzed here see the responsibility of greenspace justice, at least in part, attributed to urban planning. Our sample of park management researchers characterize real estate development as responsible for injustice in greenspace [45]. Public health researchers look at transportation networks as determinants of access to greenspace [33], as well as land use zoning and stakeholder engagement [34]. Urban forestry researchers blame land use zoning [38,40], uneven public investment, policies and regulations for injustice in greenspace [39]. Water management researchers see the federal housing policy as responsible for the deplorable state of alleys [47], as well as land tenure issues [48]. Conservation of biodiversity researchers also see responsibilities for injustice in land use type and period-specific urban planning trends [51], as well as competition for space [50].

Our findings show that, like responsibilities, the solutions to greenspace injustice are found in multiple disciplines. For example, public health researchers highlight how transportation networks that include biking and walking tracks leading to greenspace (a task for urban planners) may provide easier access to people and this may enhance their level of physical activity and health [33]. In addition, our sample of studies from public health research also suggests that greenspace should be designed to include multiple functions [33], which calls attention to landscape designers and water managers for stormwater management. Likewise, urban forestry researchers see the solutions to greenspace injustice in policies that fund implementation and maintenance of greenspace [38], and control of urban growth [40], which corresponds to urban planning professionals.

Community engagement is seen by many disciplines as a procedural antidote to greenspace injustice. Landscape architecture researchers suggest community tree planting initiatives to strengthen social interactions [43]. Water management researchers suggest that lack of engagement can be linked to poor maintenance practices of greenspace [48]; and building capacity is needed to address these issues [49]. Similarly, urban planning researchers call for community participation in regeneration actions [36]; urban forestry researchers suggest considering the needs of low-income communities in tree planting initiatives [39]; and park management researchers recommend considering the usage patterns of marginalized groups [44].

\section{Discussion and Conclusions}

Our review of the diverse disciplinary approaches to justice in urban greenspace reveals several notable patterns and trends in the research. We find that most authors define justice, or its corollary concepts of inequality and inequity, in terms of the equal distribution of its benefits among all groups of urban residents with a framing grounded in an ethical and fairness perspective. Most researchers see justice in distribution of greenspace the most common notion of greenspace justice, but some disciplines look mostly at the procedural perspective. In terms of rights overlooked in greenspace justice, we expected to find issues mostly related to environmental racism [12]. Although we found that non-whites and immigrants are the excluded groups in many studies, our findings suggest it is largely an issue related to income. Low-income people broadly defined (e.g., unemployed, renters, immigrants, non-whites, people with low educational level), are the most vulnerable in terms of access 
to urban greenspace with their rights being overlooked or ignored. But vulnerable groups exist that are not necessarily related to income and should be recognized in justice efforts, including females, elderly, youth, people living in high density neighborhoods, people living in flood-prone areas, and future generations. Justice issues also affect non-human species [52] and there are important efforts to address them. Most notably, in France, trees have recently acquired rights to develop and reproduce freely and are now considered as a subject of law [53].

Not surprisingly, we observe that the disciplinary lens used to examine greenspace justice affects the type of justice portrayed in urban greenspace justice research. Researchers tailor their justice research to their disciplinary theories and frameworks. Yet, the various solutions proposed in the diverse streams of scholarship often call for solutions that transcend individual disciplinary boundaries. For example, in our analysis, land use zoning emerged as a cause for greenspace injustice from urban planning research [37], but also from other disciplines whose work is not related to land use zoning, including public health research [34], urban forestry research [38,40], landscape architecture research [42], and conservation of biodiversity research [54]. Therefore, to effectively address greenspace justice through land use zoning, urban planners must consider ways in which these regulations affect justice from other different disciplinary perspectives.

Recognizing these interdependences, we call for greater collaborative and cross-disciplinary work to effectively address injustice in urban greenspace. An interdisciplinary approach is necessary to design a network of connected greenspace that combines the understanding of ecological processes with system thinking at the urban landscape scale [55]. In addition, it is necessary to recognize that not all greenspace is created equal, that not all people perceive the benefits of greenspace equally, and that there are tradeoffs to consider [56]. Similarly, interdisciplinary research is needed to expedite learning and translate findings to inform policy makers. To advance sustainability goals, it is necessary to consider holistic approaches that bring together researchers and practitioners from different disciplines and fields of study to find concrete solutions [30].

Future interdisciplinary efforts can be guided by five key lessons that we distill from our review of the urban greenspace justice scholarship. These include: (1) appropriate funding mechanisms for long-term maintenance; (2) recognition of safety concerns; (3) connectivity of greenspace; (4) multifunctionality in greenspace design; and (5) community engagement. We envision these lessons as a framework for greenspace justice where community engagement is at the center to ensure inclusive processes (Figure 1). To allow for more just urban greenspace, scholars, built environment practitioners, and policymakers alike must account for these lessons in their future work.

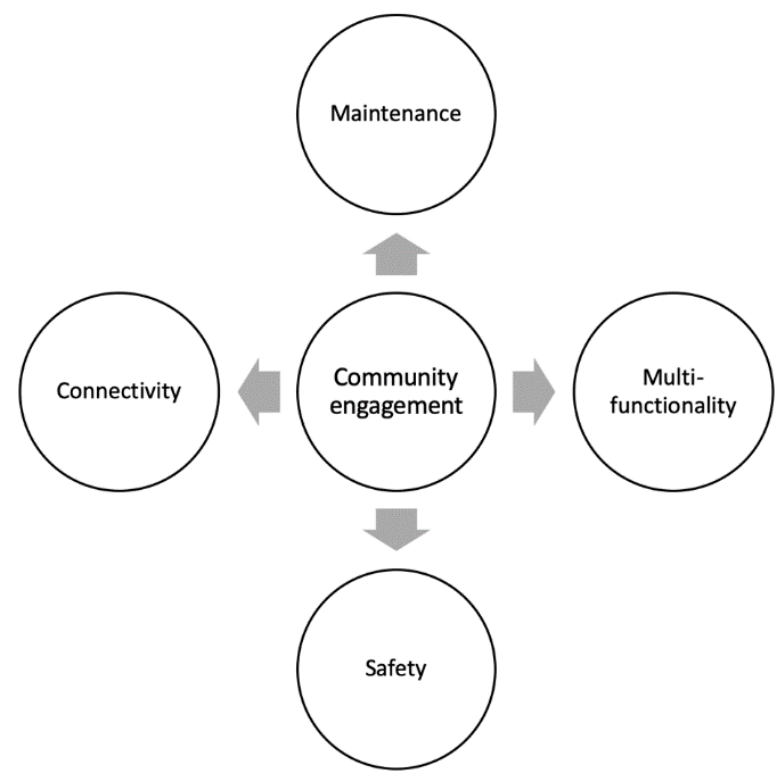

Figure 1. Framework for greenspace justice. 
First, most disciplines agree that continuous maintenance is key for ensuring that greenspace remains an amenity to urban residents [39,41,44,46,48]. However, lack of funding and changes in administration makes long term maintenance of greenspace challenging [43], which aligns with previous studies $[7,57,58]$. It is also challenging to maintain greenspace because the responsibility to do so is often times not clearly defined. For this reason, in the UK, the long-term responsibility of maintenance of green infrastructure projects is sometimes passed to a third party, which can be a private company, a water company, or a local authority [59]. In China, funding for green infrastructure and its maintenance in sponge cities has been possible through public-private partnerships [59]. To ensure continuous maintenance, greening initiatives must include some type of funding mechanism and a clear assignation of responsibilities to organisms that persist in spite of changes in administration.

Second, related to maintenance, ensuring safety in greenspace is critical for vulnerable groups, particularly females [32]. If greenspace is not maintained, it can become a space that fosters crime [41]. This finding aligns with previous studies that have shown that when there is environmental degradation, women are more susceptible [13]. But in addition to the need for a gendered assessment of safety and overall maintenance, safety is related to other features that involve multiple disciplines; including lighting, the size of the park, land use, programing of park activities, and access. According to famous urbanist Jane Jacobs, safety in parks (and other public spaces) is achieved by simply having "eyes on the streets," or attracting people within and around parks at all times [60]. Landscape architects should consider designing parks that can be easily surveilled and accessed from multiple points. Encouraging multiple activities that bring people to the park at all times is important for urban planners who can allow a mix of land uses so that vendors can work around and inside the park and to park managers who can program events for diverse groups.

Third, connectivity of greenspace has the potential to reduce greenspace injustices. Green corridors that connect large habitat patches are essential for landscape connectivity and the conservation of biodiversity [50-52]. Similarly, public health researchers suggest that connecting greenspace though linear parks that include walking and biking pathways provides opportunities for physical activity that may enhance wellbeing [33]. For landscape architects, this concept of connectivity is not new. The famous landscape architect, Frederick Law Olmstead, created interconnected parks in Boston in the 19th century, known as the Emerald Necklace, and has proven to be a valuable amenity for the residents [50]. Furthermore, stormwater management is more efficient when green infrastructure is connected across the city [47]. Also, greening streets that connect small parks is also recommended by researchers who study park management [45]. It is critical to include periurban areas of cities in the Global South in this network of greenspace, as these are vulnerable to justice issues $[35-37,40,45]$. However, the task of connecting greenspace cannot be addressed by one discipline alone; it involves urban planners, water managers, urban foresters, conservationists, and visionary landscape architects. Some cities in Europe are pursuing these type of regional planning initiatives aimed to connect larger ecological reserves (e.g., Europe's Natura 2000) [61]. Likewise, water managers in the UK and China are working hard to combine standalone green infrastructure projects into a 'management train' to achieve cumulative benefits for flood management [59].

Fourth, designing greenspace that serves multiple functions is a key lesson to reduce injustice from the diverse research studied here. For water managers it is important to use all available urban infrastructure to manage stormwater in a decentralized way, including alleys that provide recreational space and safe walking routes to residents [47]. Attracting a diversity of users is also related to safety. Having multiple functions prevents the appropriation of greenspace by a particular group [37]. This notion of fostering multiple functions in greenspace aligns with other findings that speak of the importance of bringing different population groups together for city vitality and sense of community [60], and the need to use open spaces to manage stormwater for urban resilience (6). According to Lähde et al. [55], from stormwater management research, the multifunctionality of greenspace should be considered during the design stage, including biodiversity, amenities, water quantity and water quality. These functions 
are context specific and depend on the surrounding elements as well as their continuous functioning (e.g., if biodiversity declines, so does water quality) $(55,61)$.

Finally, we observe that community engagement is critical to ensure all voices are considered in the process of greenspace design, implementation, and management and avoid injustices. Here, the need to have inclusive processes was identified by most disciplines (Table 3). Community engagement has also been identified as critical in previous studies on urban resilience $[7,62,63]$. But there is an important caveat to consider. Although many researchers highlight the need for community engagement to ensure vulnerable voices are heard, in practice, this process itself is subject to justice issues. Low income families may not have the same time availability as others to participate in community engagement processes. Renters may not be inclined to participate in greening efforts. Often times, underserved communities have disinvested neighborhood associations, which makes it more challenging for organizations to engage with them [48]. Therefore, it is necessary to direct resources to engagement efforts that require trust, which takes time and effort to achieve. Cross-disciplinary approaches show promise to successfully engage communities and bring people with different interests together [64]. Successful community engagement efforts show the need for collaboration not only among disciplines, but also between local and state governments, NGOs, schools, and community-based organizations [65]. From their successful community engagement work in Detroit, U.S., Hartig and Wallace [66] extract lessons that include the recruitment of a champion, the support of local groups, the development of a delivery team, an approach focused on outcomes, and the measurement of success. These efforts, when combined with a capacity building component can result in an enhanced sense of community and higher appreciation for the benefits of greenspace [64].

Universities are likely to have an important role in promoting interdisciplinary processes and pathways in terms of research and student training, and to facilitate interactions between stakeholders and communities. Shandas and Messer [67] found that university-community partnerships are key for the effectiveness of stewardship programs, and flexible approaches are needed to allow innovation in the engagement process. University students have an important role to play in engagement projects. Willmore et al. [68] argue that often times the capacity of young people is undervalued in sustainability efforts, yet engaging the youth offers important opportunities for community engagement, as well as individual and community resilience.

Greater cross-disciplinary work is needed to achieve justice objectives. Built environment professionals must work together to ensure inclusive processes and address greenspace injustices. There are some successful examples of interdisciplinary work around greenspace, as shown in Tucson, Arizona, where a working group composed of water managers, city and county officials, local organizations, and academics meets regularly to advance policy and action on greening practices [69]. Future work is needed to examine the effectiveness of interdisciplinary efforts to address greenspace justice, and to explore questions related to data reliability and availability in measuring all greenspace within a city, country, or region. Ultimately, scholars, built environment practitioners, and policymakers must work together to engage community members in ways that appropriately address the underlying causes that lead to greenspace injustice and to craft the appropriate solutions going forward.

Author Contributions: Both authors contributed to the writing and analysis of this study.

Acknowledgments: This work was funded by the Agnese Nelms Haury Program in Environment and Social Justice at the University of Arizona. We also received support from the International Water Security Network funded by the Lloyd's Register Foundation, a charitable foundation helping to protect life and property by supporting engineering-related education, public engagement, and the application of research. We also received support from the Inter American Institute for Global Change Research (IAI) CRN3056, which is supported by the National Science Foundation [GEO-1128040]. We acknowledge support of the Morris K. Udall and Stewart L. Udall Foundation for open-access publishing fees.

Conflicts of Interest: The authors declare no conflict of interest. 


\section{References}

1. Ambrey, C.L. Greenspace, physical activity and well-being in Australian capital cities: How does population size moderate the relationship? Public Health 2016, 133, 38-44. [CrossRef] [PubMed]

2. Herrick, C. Designing the fit city: Public health, active lives, and the (re)instrumentalization of urban space. Environ. Plan A 2009, 41, 2437-2454. [CrossRef]

3. Hordyk, S.R.; Hanley, J.; Richard, É. "Nature is there; its free”: Urban greenspace and the social determinants of health of immigrant families. Health Place 2015, 34, 74-82. [CrossRef]

4. Mavoa, S.; Koohsari, M.J.; Badland, H.M.; Davern, M.; Feng, X.; Astell-Burt, T.; Giles-Corti, B. Area-Level Disparities of Public Open Space: A Geographic Information Systems Analysis in Metropolitan Melbourne. Urban Policy Res. 2015, 33, 306-323. [CrossRef]

5. Sandifer, P.A.; Sutton-Grier, A.E.; Ward, B.P. Exploring connections among nature, biodiversity, ecosystem services, and human health and well-being: Opportunities to enhance health and biodiversity conservation. Ecosyst. Serv. 2015, 12, 1-15. [CrossRef]

6. Staddon, C.; Ward, S.; De Vito, L.; Zuniga-Teran, A.; Gerlak, A.; Schoeman, Y.; Hart, A.; Booth, G. Contributions of green infrastructure to enhancing urban resilience. Environ. Syst. Decis. 2018, 38, 330. [CrossRef]

7. Zuniga-Teran, A.; Staddon, C.; De Vito, L.; Gerlak, A.K.; Ward, S.; Schoeman, Y.; Hart, A.; Booth, G. Challenges of mainstreaming green infrastructure in built environment professions. J. Environ. Plan. Manag. 2019. [CrossRef]

8. Bryant, M.M. Urban landscape conservation and the role of ecological greenways at local and metropolitan scales. Landsc. Urban Plan. 2006, 76, 23-44. [CrossRef]

9. Hartig, T.; Mitchell, R.; de Vries, S.; Frumkin, H. Nature and Health. Annu. Rev. Public Health 2014, 35, 207-228. [CrossRef]

10. Boone, C.G.; Buckley, G.L.; Grove, J.M.; Sister, C. Parks and people: An Environmental Justice Inquiry in Baltimore, Maryland. Annu. Assoc. Am. Geogr. 2009, 99, 767-787. [CrossRef]

11. Heckert, M. Access and Equity in Greenspace Provision: A Comparison of Methods to Assess the Impacts of Greening Vacant Land: Access and Equity in Greenspace Provision. Trans. GIS 2013, 17, 808-827. [CrossRef]

12. Walker, G. Environmental Justice: Concepts, Evidence and Politics; Routledge Taylor and Francis: London, UK, 2012; p. 255.

13. MacBride-Stewart, S.; Gong, Y.; Antell, J. Exploring the interconnections between gender, health and nature. Public Health 2016, 141, 279-286. [CrossRef] [PubMed]

14. Jennings, V.; Johnson Gaither, C.; Gragg, R.S. Promoting Environmental Justice Through Urban Green Space Access: A Synopsis. Environ. Justice 2012, 5, 1-7. [CrossRef]

15. Nelson, J.; Grubesic, T. Environmental Justice: A Panoptic Overview Using Scientometrics. Sustainability 2018, 10, 1022. [CrossRef]

16. Heynen, N.; Perkins, H.A.; Roy, P. The Political Ecology of Uneven Urban Green Space: The Impact of Political Economy on Race and Ethnicity in Producing Environmental Inequality in Milwaukee. Urban Aff. Rev. 2006, 42, 3-25. [CrossRef]

17. Almeter, A.; Tashie, A.; Procter, A.; McAlexander, T.; Browning, D.; Rudder, C.; Jackson, L.; Araujo, R. A Needs-Driven, Multi-Objective Approach to Allocate Urban Ecosystem Services from 10,000 Trees. Sustainability 2018, 10, 4488. [CrossRef]

18. Mabon, L.; Shih, W.-Y. What might 'just green enough' urban development mean in the context of climate change adaptation? The case of urban greenspace planning in Taipei Metropolis, Taiwan. World Dev. 2018, 107, 224-238. [CrossRef]

19. Tao, Z.; Grove, M. A Discourse on landscape architecture: At the intersection of design, ecology, resilience, and research. Landsc. Archit. Front. 2018, 6, 54. [CrossRef]

20. Wendel, H.E.W.; Downs, J.A.; Mihelcic, J.R. Assessing Equitable Access to Urban Green Space: The Role of Engineered Water Infrastructure. Environ. Sci. Technol. 2011, 45, 6728-6734. [CrossRef] [PubMed]

21. Brink, E.; Aalders, T.; Ádám, D.; Feller, R.; Henselek, Y.; Hoffmann, A.; Ibe, K.; Matthey-Doret, A.; Meyer, M.; Negrut, N.L.; et al. Cascades of green: A review of ecosystem-based adaptation in urban areas. Glob. Environ. Chang. 2016, 36, 111-123. [CrossRef] 
22. Horst, M.; McClintock, N.; Hoey, L. The Intersection of Planning, Urban Agriculture, and Food Justice: A Review of the Literature. J. Am. Plann. Assoc. 2017, 83, 277-295. [CrossRef]

23. Feng, Y.; Tan, P.Y. Imperatives for greening cities: A historical perspective. In Greening Cities; Tan, P.Y., Jim, C.Y., Eds.; Springer: Singapore, 2017; pp. 41-70.

24. Bulkeley, H.; Edwards, G.A.S.; Fuller, S. Contesting climate justice in the city: Examining politics and practice in urban climate change experiments. Glob. Environ. Change. 2014, 25, 31-40. [CrossRef]

25. Schlosberg, D. Theorising environmental justice: The expanding sphere of a discourse. Environ. Polit. 2013, 22, 37-55. [CrossRef]

26. Fernández, I.C.; Wu, J. A GIS-based framework to identify priority areas for urban environmental inequity mitigation and its application in Santiago de Chile. Appl. Geogr. 2018, 94, 213-222. [CrossRef]

27. Environmental Protection Agency. Environmental Justice. Available online: https://www.epa.gov/ environmentaljustice (accessed on 15 April 2019).

28. Agyeman, J.; Schlosberg, D.; Craven, L.; Matthews, C. Trends and Directions in Environmental Justice: From Inequity to Everyday Life, Community, and Just Sustainabilities. Annu. Rev. Environ. Resour. 2016, 41, 321-340. [CrossRef]

29. Toffolon-Weiss, M.; Roberts, T. Chapter 5: Who wins, who loses? Understanding outcomes of environmental injustice struggles. In Power, Justice and the Environment; Pellow, D., Brulle, R., Eds.; MIT Press: Cambridge, MA, USA, 2005; pp. 77-90.

30. Perkumienè, D.; Pranskūnienè, R. Overtourism: Between the Right to Travel and Residents' Rights. Sustainability 2019, 11, 2138. [CrossRef]

31. Boulton, C.; Dedekorkut-Howes, A.; Byrne, J. Factors shaping urban greenspace provision: A systematic review of the literature. Landsc. Urban Plan. 2018, 178, 82-101. [CrossRef]

32. Ambrey, C.L.; Shahni, T.J. Greenspace and wellbeing in Tehran: A relationship conditional on a neighbourhood's crime rate? Urban Urban Green 2017, 27, 155-161. [CrossRef]

33. Ngom, R.; Gosselin, P.; Blais, C. Reduction of disparities in access to green spaces: Their geographic insertion and recreational functions matter. Appl. Geogr. 2016, 66, 35-51. [CrossRef]

34. Cole, H.V.S.; Garcia Lamarca, M.; Connolly, J.J.T.; Anguelovski, I. Are green cities healthy and equitable? Unpacking the relationship between health, green space and gentrification. J. Epidemiol. Commun. Health 2017, 71, 1118-1121. [CrossRef]

35. Nero, B.F. Urban green space dynamics and socio-environmental inequity: Multi-resolution and spatiotemporal data analysis of Kumasi, Ghana. Int. J. Remote Sens. 2017, 38, 6993-7020. [CrossRef]

36. Rutt, R.L.; Gulsrud, N.M. Green justice in the city: A new agenda for urban green space research in Europe. Urban Urban Green 2016, 19, 123-127. [CrossRef]

37. Wolch, J.R.; Byrne, J.; Newell, J.P. Urban green space, public health, and environmental justice: The challenge of making cities 'just green enough'. Landsc. Urban Plan. 2014, 125, 234-244. [CrossRef]

38. Nesbitt, L.; Meitner, M. Exploring Relationships between Socioeconomic Background and Urban Greenery in Portland, OR. Forests 2016, 7, 162. [CrossRef]

39. Schwarz, K.; Fragkias, M.; Boone, C.; Zhou, W.; McHale, M.; Grove, M.; O’Neil-Dunne, J.; McFadden, J.; Buckley, G.L.; Childers, D.; et al. Trees grow on money: Urban tree canopy cover and environmental justice. PLOS ONE 2015, 10, 17. [CrossRef]

40. Escobedo, F.J.; Clerici, N.; Staudhammer, C.L.; Corzo, G.T. Socio-ecological dynamics and inequality in Bogotá, Colombia's public urban forests and their ecosystem services. Urban Urban Green. 2015, 14, 1040-1053. [CrossRef]

41. Larson, S.M. Imagining social justice and the false promise of urban park design. Environ. Plan. Econ. Space 2018, 50, 391-406. [CrossRef]

42. Zimmer, A.; Cornea, N.; Véron, R. Of parks and politics: The production of socio-nature in a Gujarati town. Local Environ. 2017, 22, 49-66. [CrossRef]

43. Roman, L.A.; Fristensky, J.P.; Eisenman, T.S.; Greenfield, E.J.; Lundgren, R.E.; Cerwinka, C.E.; Hewitt, D.A.; Welsh, C.C. Growing Canopy on a College Campus: Understanding Urban Forest Change through Archival Records and Aerial Photography. Environ. Manage. 2017, 60, 1042-1061. [CrossRef] 
44. Willemse, L. Some perceptions and preferences of residents' use of community neighbourhood parks in Mitchells Plain, Cape Town. Town Reg. Plan. 2015, 66, 16.

45. Yuan, Y.; Xu, J.; Wang, Z. Spatial Equity Measure on Urban Ecological Space Layout Based on Accessibility of Socially Vulnerable Groups-A Case Study of Changting, China. Sustainability 2017, 9, 1552. [CrossRef]

46. Kimpton, A. A spatial analytic approach for classifying greenspace and comparing greenspace social equity. Appl. Geogr. 2017, 82, 129-142. [CrossRef]

47. Newell, J.P.; Seymour, M.; Yee, T.; Renteria, J.; Longcore, T.; Wolch, J.R.; Shishkovsky, A. Green Alley Programs: Planning for a sustainable urban infrastructure? Cities 2013, 31, 144-155. [CrossRef]

48. Heckert, M.; Rosan, C.D. Developing a green infrastructure equity index to promote equity planning. Urban Urban Green. 2016, 19, 263-270. [CrossRef]

49. Mandarano, L.; Meenar, M. Equitable distribution of green stormwater infrastructure: A capacity-based framework for implementation in disadvantaged communities. Local Environ. 2017,22, 1338-1357. [CrossRef]

50. Strohbach, M.W.; Lerman, S.B.; Warren, P.S. Are small greening areas enhancing bird diversity? Insights from community-driven greening projects in Boston. Landsc. Urban Plan. 2013, 114, 69-79. [CrossRef]

51. Cohen, M.; Baudoin, R.; Palibrk, M.; Persyn, N.; Rhein, C. Urban biodiversity and social inequalities in built-up cities: New evidences, next questions. The example of Paris, France. Landsc. Urban Plan. 2012, 106, 277-287. [CrossRef]

52. Steele, W.; Mata, L.; Fünfgeld, H. Urban climate justice: Creating sustainable pathways for humans and other species. Curr. Opin. Environ. Sustain. 2015, 14, 121-126. [CrossRef]

53. Smits, J. France Proclaims Trees Should have Rights. Declaration of Tree Rights. 2019. Available online: https://www.lifesitenews.com/tags/tag/declaration+of+tree+rights (accessed on 27 April 2019).

54. Cohen, P.; Potchter, O.; Matzarakis, A. Daily and Seasonal Climatic Conditions of Green Urban open Spaces in the Mediterranean Climate and their Impact on Human Comfort. Build Environ. Available online: http://www.sciencedirect.com/science/article/pii/S0360132311004100 (accessed on 4 December 2012).

55. Lähde, E.; Khadka, A.; Tahvonen, O.; Kokkonen, T. Can We Really Have It All?—Designing Multifunctionality with Sustainable Urban Drainage System Elements. Sustainability 2019, 11, 1854. [CrossRef]

56. Jennings, V.; Floyd, M.F.; Shanahan, D.; Coutts, C.; Sinykin, A. Emerging issues in urban ecology: Implications for research, social justice, human health, and well-being. Popul. Environ. 2017, 39, 69-86. [CrossRef]

57. Furlong, C.; Phelan, K.; Dodson, J. The role of water utilities in urban greening: A case study of Melbourne, Australia. Util. Policy 2018, 53, 25-31. [CrossRef]

58. Hoang, L.; Fenner, R.A. System interactions of stormwater management using sustainable urban drainage systems and green infrastructure. Urban Water J. 2016, 13, 739-758. [CrossRef]

59. Lashford, C.; Rubinato, M.; Cai, Y.; Hou, J.; Abolfathi, S.; Coupe, S.; Charlesworth, S.; Tait, S. SuDS \& Sponge Cities: A Comparative Analysis of the Implementation of Pluvial Flood Management in the UK and China. Sustainability 2019, 11, 213.

60. Jacobs, J. The Death and Life of Great American Cities; Modern Library: New York, NY, USA, 1961.

61. Staddon, C.; De Vito, L.; Zuniga-Teran, A.; Schoeman, Y.; Hart, A.; Booth, G. Contributions of green infrastructure to enhancing urban resilience: Agenda setting scoping studies. The Resilience Shift 2017. Available online: https://resilienceshift.org/wp-content/uploads/2017/10/043_Contributions-of-Green-Infrastructure-toEnhancing-Urban-Resilience.pdf (accessed on 23 March 2018).

62. Petts, J. Public engagement to build trust: False hopes? J. Risk Res. 2008, 11, 821-835. [CrossRef]

63. Urban Land Institute. The Ten Principles for Building Resilience. Available online: https:/americas.uli.org/ wp-content/uploads/sites/125/ULI-Documents/10P_BuildingResilience.pdf (accessed on 23 March 2018).

64. Ahn, C.; Schmidt, S. Designing Wetlands as an Essential Infrastructural Element for Urban Development in the era of Climate Change. Sustainability 2019, 11, 1920. [CrossRef]

65. Sadeghi, M.; Kharaghani, S.; Tam, W.; Gaerlan, N.; Loaiciga, H. Avalon Green Alley Network: Low Impact Development (LID) Demonstration Project in Los Angeles, California. In Proceedings of the World Environmental and Water Resources Congress, West Palm Beach, FL, USA, 22-26 May 2016; pp. 205-214.

66. Hartig, J.; Wallace, M. Creating World-Class Gathering Places for People and Wildlife along the Detroit Riverfront, Michigan, USA. Sustainability 2015, 7, 15073-15098. [CrossRef] 
67. Shandas, V.; Messer, W.B. Fostering Green Communities Through Civic Engagement: Community-Based Environmental Stewardship in the Portland Area. J. Am. Plann. Assoc. 2008, 74, 408-418. [CrossRef]

68. Willmore, C.; Longhurst, J.; Calyton, W.; Tweddell, H.; Walsh, A. Young people's role in creating sustainable cities. In Lifelong Learning and Eductaion in Healthy and Sustainable Cities; Azeiteiro, U., Akerman, M., Leal Filho, W., Setti, A., Brandli, L., Eds.; Springer: Cham, Switzerland, 2018.

69. Pima County. Low Impact Development. Available online: https://webcms.pima.gov/cms/one.aspx?pageId= 65263 (accessed on 22 April 2019).

(C) 2019 by the authors. Licensee MDPI, Basel, Switzerland. This article is an open access article distributed under the terms and conditions of the Creative Commons Attribution (CC BY) license (http://creativecommons.org/licenses/by/4.0/). 